\title{
Social Business: A Revolutionary Idea in the Field of Poverty Alleviation
}

\author{
Sayema Hoque
}

\begin{abstract}
Poverty is one of the major problems around the world. Prof. Dr. Muhammad Yunus has come up with a revolutionary idea to solve that problem by introducing the social business concept which emphasizes a combined and organized effort of poverty alleviation through selfsustaining business mechanism. This paper attempts to overview of the idea, discuss current practice of social business in Bangladesh; and compare social business model with other existing business models.
\end{abstract}

Key Words: Poverty alleviation, social responsibility, social business, business model

\section{Introduction}

Exclusive profit maximizing motive of capitalist economy has been largely responsible for creating poverty across the world. In the face of pervasive poverty, the United Nations Development Program (UNDP) in 2000 set number one goal of halving extreme poverty (measured by the proportion of people living on less than $\$ 1$ a day) by 2015 (UNDP website). More than a decade has passed since the declaration was adopted, but still more than one billion people belong to the pool of extreme poverty (World Hunger website). In response to the apparent failure of traditional capitalism, corporate social responsibility (CSR) is seen to have emerged in order to enable it to protect the interest of the poor people as well as to facilitate profit earning. Even a business company which adopts CSR approach does not pay enough attention to CSR related activities because its prime goal is to maximize shareholders' profit. As a result, the impact of CSR on poverty

\footnotetext{
${ }^{*}$ Lecturer in Accounting, Department of Business Administration, IIUC.
} 
situation is proved insignificant. Moreover, it is alleged that most of the times the profit maximizing business (PMB) companies use CSR activities as the tool of business promotion rather than a tool of eradicating poverty. One may believe that government organizations can provide products or services at lower price without any profit motive to fulfill social objective like poverty alleviation but government alone cannot solve all the societal problems. Sometimes by its very nature government may suffer from huge loss and ultimate burden goes to the general people. There is also a perception that organizations of charity nature like, NGOs and aid agencies, which are sponsored by rich governments and organizations, can have a good handle in solving societal problem including poverty. But since these organizations are dependent on charity and aids, they cannot run their business on a sustainable basis. Once the flows of aids and charity are stopped, all their good steps ceases to exist. In this backdrop, Dr. Muhammad Yunus, the 2006 Nobel Peace Prize winner, came up with the revolutionary idea of social business. The concept first appeared in his New York Times Bestseller book 'Banker to the Poor: Microlending and the Battle against World Poverty' in 2007.

\section{Literature Review}

As Social Business is a very recent idea, the literature contains only a few studies.

Bylund and Mondelli (2009) identify free-riding as one of the problems in the evolution of social business. They argue that social business is not a widely observed phenomenon because of a weaker incentive to minimize cost and maximize output. They term social business as a very difficult enterprise.

Wimmer (2012), while analyzing the activities of Grameen Shakti, describes how a social business can change the daily lives of rural population. She sees the sense of responsibility to the society as the driving force of such a business company.

Referring to the aspects of public health, Donaldson et al. (2011) analyze the reasons why social business represents an important area of consideration for public policy given the limits of traditional businesses. They observe that social businesses in the health care contexts as well as in the non-health care contexts can have a considerable impact on health and overall wellbeing. 
According to Sattar (2012), social business reins the pursuit of profit maximization and hence gives some relief within the capitalist system.

This study attempts to discuss the overview of the idea, current practice of social business in Bangladesh and comparison of social business model with other existing business models.

\section{Objectives of the Study}

The main objective of the study is to provide an analytical presentation of the Social Business concept. The specific objectives of the study include the following:

i. To identify the basic theme, model, types and principles of social business approach;

ii. To analyze the welfare implications of the social business;

iii. To compare the social business with other business models;

iv. To evaluate the social business scenario in Bangladesh; and

v. To identify some limitations and criticism of social business concept.

\section{Methodology of the Study}

Data and information: This article is based on information collected from various secondary sources including books on social business authored by Dr. Muhammad Yunus, different articles on social business, business ethics and social responsibility, and a few related websites.

Analytical framework: The analysis will be mainly based on description. In case of necessity, simple tabular presentations may appear. Statistical and econometric analyses are not feasible options due to the fact that the social business is a new concept and necessary data are not yet available.

\section{What is a Social Business?}

A social business is defined as a business entity which is run on the basis of "non-loss-non-dividend" motive and the ultimate goal of which is to solve social problems especially those related to poverty. In Yunus' words, "A social business is designed and operated as a business enterprise, with products, services, customers, markets, expenses, and revenues. It is a no loss, no dividend, self sustaining company that sells goods or services and payback investments to its 
owners, but whose primary purpose is to serve society and improve the lot of the poor" (Yunus and Weber 2007b).

A Social Business can roughly be characterized by the following properties:

i. It is not primarily a charitable organization, but a competitive enterprise.

ii. It needs to recover its full costs in order to achieve selfsustainability.

iii. The owner never receives any profits/dividends. He, however, is entitled to get back his invested amount only.

iv. Profit can be reinvested to expand the business. It can also be passed on to target group such as poor people by lowering price and providing better service.

v. A social business aims at maximizing social benefits instead of profit. It tries to achieve social objectives rather than personal gain.

World renowned weekly business magazine Business Week commented on social business this way, "......Yunus goes beyond microcredit to pioneer the idea of social business- a completely new way to use the creative vibrancy of business to tackle social problems from poverty and pollution to inadequate health care and lack of education. Yunus's "Next Big Idea" offers a pioneering model for nothing less than a new, more humane form of capitalism." (Yunus and Weber 2007b).

\section{Types of Social Businesses}

Yunus classified social business into two types on the basis of its construct (Yunus and Weber 2007a). They are Type I and Type II.

Type I: This type includes those companies that are established with a view to achieving a specific social, ethical or environmental goal through providing goods or services at a price easily reachable by the members of the target group. Grameen Danone, a yogurt producing company operating in Bangladesh, may be given as an appropriate example of Type I company. It has been established with the particular objective of solving nutrition problem in the rural area among the poor population. The yogurt it produces has high content of vitamins and 
other nutritional elements. The price of yogurt is set at a level just enough to recover the cost excluding entrepreneurs' profit and thus enabling poor parents to meet their children's nutritional need.

Type II: A social business company is identified as Type II if the poor people are made the owner of the company. Although business is operated on traditional basis under this framework, it is the poor people who gain ultimate benefits through receiving dividends. While in Type I case poor people enjoy the benefits by acting as buyers, in the Type II case they gain the benefits by playing role of sellers. Grameen Bank may be set in place as an example of Type II company, because it is predominantly owned by thousands of poor. However, the Grameen Bank also has characteristics of Type I. Since its inception it has been extending credit facilities to the underprivileged who otherwise would have been with little opportunity to access in the credit markets.

7. Social Business versus Profit Maximizing Business (PMB) and Not-for-profit Organizations

There are both similarities and dissimilarities between social business, PMB and not-for-profit organizations. A comparison is made in Table-1.

Table1: Comparison between social business, PMB and not-forprofit organizations

\begin{tabular}{|c|c|c|c|}
\hline $\begin{array}{c}\text { Basis of } \\
\text { comparison }\end{array}$ & $\begin{array}{c}\text { Profit maximizing } \\
\text { business }\end{array}$ & $\begin{array}{c}\text { Not-for-profit } \\
\text { organizations }\end{array}$ & Social business \\
\hline $\begin{array}{c}\text { Profit } \\
\text { equation }\end{array}$ & $\begin{array}{c}\text { Economic profit } \\
\text { equation exists. }\end{array}$ & $\begin{array}{c}\text { No economic profit } \\
\text { equation }\end{array}$ & $\begin{array}{c}\text { Economic profit } \\
\text { equation exists. }\end{array}$ \\
\hline $\begin{array}{c}\text { Dividend } \\
\text { distribution }\end{array}$ & $\begin{array}{c}\text { Dividend is } \\
\text { distributed to } \\
\text { owners. }\end{array}$ & $\begin{array}{c}\text { No dividend is } \\
\text { distributed to } \\
\text { owner. }\end{array}$ & $\begin{array}{c}\text { No dividend is } \\
\text { distributed to } \\
\text { owner. }\end{array}$ \\
\hline
\end{tabular}




\begin{tabular}{|c|c|c|c|}
\hline $\begin{array}{c}\text { Social } \\
\text { responsibility }\end{array}$ & $\begin{array}{l}\text { No responsibility to } \\
\text { fulfill social } \\
\text { objectives except } \\
\text { some legally non- } \\
\text { mandatory CSR. }\end{array}$ & $\begin{array}{l}\text { Objective is only to } \\
\text { fulfill social goals. }\end{array}$ & $\begin{array}{l}\text { Main objective is } \\
\text { to fulfill social } \\
\text { goals. }\end{array}$ \\
\hline $\begin{array}{l}\text { Return of } \\
\text { capital }\end{array}$ & $\begin{array}{c}\text { Capital is returned to } \\
\text { the owners. }\end{array}$ & No return of capital & $\begin{array}{c}\text { Capital is returned } \\
\text { to the owners. }\end{array}$ \\
\hline $\begin{array}{c}\text { Self } \\
\text { sustainability }\end{array}$ & $\begin{array}{l}\text { Self sustainability } \\
\text { must be maintained. }\end{array}$ & $\begin{array}{l}\text { Dependency on } \\
\text { charities and } \\
\text { donations }\end{array}$ & $\begin{array}{c}\text { Self sustainability } \\
\text { must be } \\
\text { maintained. }\end{array}$ \\
\hline $\begin{array}{l}\text { Driving } \\
\text { factor }\end{array}$ & $\begin{array}{c}\text { Profit driven } \\
\text { business }\end{array}$ & $\begin{array}{c}\text { Cause driven } \\
\text { business }\end{array}$ & $\begin{array}{c}\text { Cause driven } \\
\text { business }\end{array}$ \\
\hline $\begin{array}{l}\text { Owners and } \\
\text { financiers of } \\
\text { the business }\end{array}$ & $\begin{array}{c}\text { Owned and financed } \\
\text { by some }\end{array}$ & $\begin{array}{l}\text { Owned by none but } \\
\text { financed by donors }\end{array}$ & $\begin{array}{c}\text { Owned and } \\
\text { financed by some }\end{array}$ \\
\hline Competition & $\begin{array}{l}\text { Competition among } \\
\text { firms is possible. }\end{array}$ & $\begin{array}{l}\text { No competition } \\
\text { with one another. }\end{array}$ & $\begin{array}{l}\text { Competition } \\
\text { among firms is } \\
\text { possible. }\end{array}$ \\
\hline $\begin{array}{l}\text { Main } \\
\text { concern }\end{array}$ & $\begin{array}{l}\text { Only concerned } \\
\text { about } \\
\text { shareholders' profit } \\
\text { maximization }\end{array}$ & $\begin{array}{l}\text { Only concerned } \\
\text { about social profit } \\
\text { maximization }\end{array}$ & $\begin{array}{l}\text { Concerned about } \\
\text { social profit } \\
\text { maximization as } \\
\text { well as recovery of } \\
\text { full cost }\end{array}$ \\
\hline
\end{tabular}

Source: Constructed by the author on the basis of information found from Yunus and Weber (2007a)

\section{Seven Principles of Social Business}

In order to establish and run a social business company, one has to comply with certain standards and norms that will guide him through his journey towards reaching the intended social goals. Dr. Muhammad Yunus and Hans Reitz, the co-founder of Grameen Creative Lab, figured out seven principles to follow (Yunus and Weber 2010):

i. Business objective is to overcome poverty, or one or more problems (such as education, health, technology access, and 
environment) that threaten people and society- not to maximize profit.

ii. The company will attain financial and economic sustainability.

iii. Investors get back only their investment amount. No dividend is given beyond the return of the original investment.

iv. When investment amount is paid back, profit stays with the company for expansion and improvement.

v. The company will be environmentally conscious.

vi. The workforce gets market wage with better-than-standard working conditions.

vii. Do it with joy!!!

\section{Components: Social Business Model vs. Traditional Business Model}

In the traditional framework, a successful business model has three components- value proposition, value constellation and profit equation. Business model in the social business framework also has these components. But here the structures of the components are somewhat different. In the social business model the profit equation is divided into economic profit equation and social profit equation. This classification is made to incorporate broad range of stakeholders and to consider environmental and other social issues. Moreover, the economic profit equation targets only full recovery of cost and capital, and not financial profit maximization. Figure 1 and 2 may be helpful in understanding the difference between the components' structure of traditional and social business model (Yunus et al. 2009):

Figure 1: Components of traditional business model

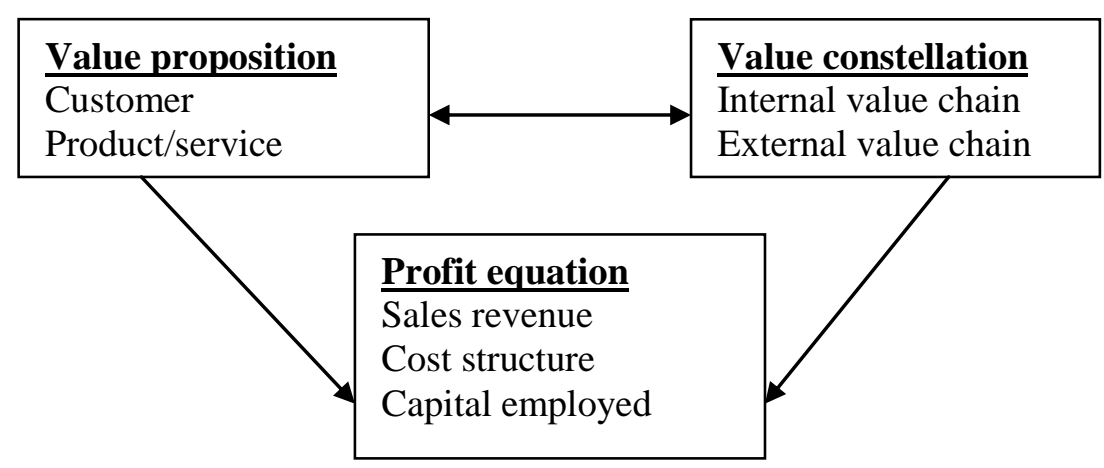


Figure 2: Components of social business model

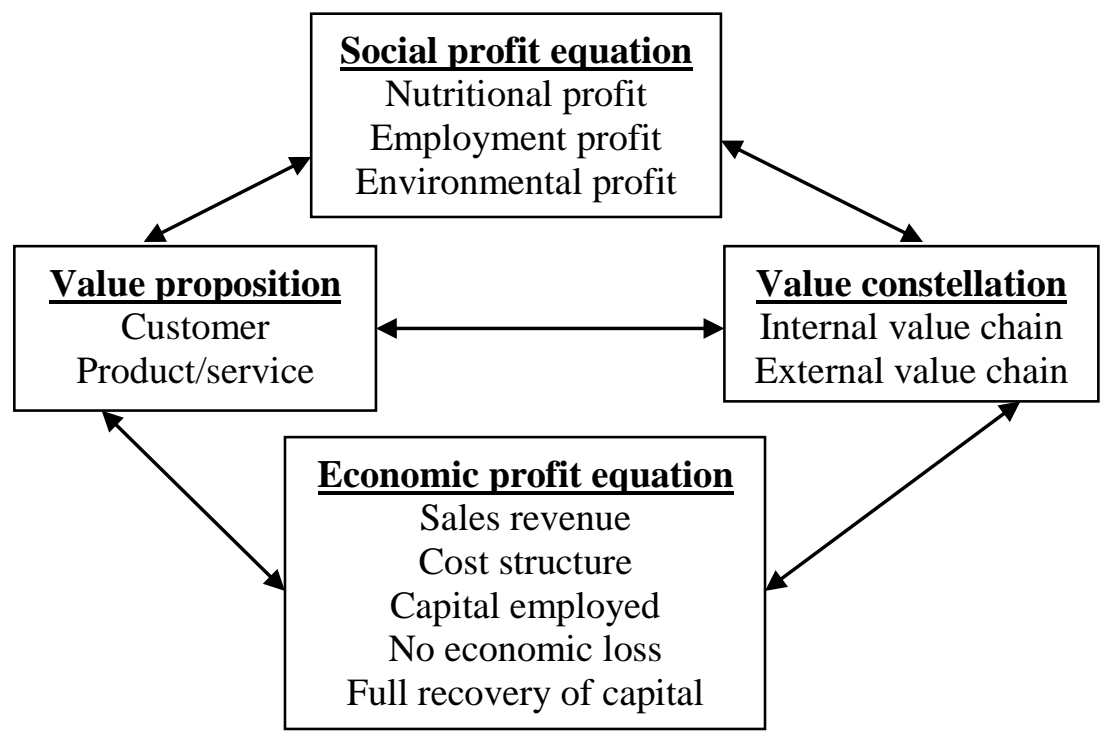

\section{Implications of Social Business for Social Welfare}

On the basis of the theoretical design and construct of the social business model the following welfare implications of it can be inferred:

Poverty alleviation: Poverty alleviation, the ultimate goal of social business model, can be achieved in two ways. Type I social business will lift the living standard of poor by providing their basic needs at reachable prices. On the other hand, type II will enhance their money income by making them self-entrepreneurs.

Employment generation: Huge employment opportunities for the poor can be generated through supply, production, and distribution channels. By the construction of the model poor people will get the priority in the recruitment process of a social business company.

Low price goods and services for the poor: Social business is supposed to provide low price goods and services such as education, food, nutrition, sanitation, technology etc. Lower price may become the main competitive advantage of the social business. 
Protecting climate and eco-system: One of the seven principles of social business is to be environmentally conscious. Its environment friendly product and activities can be an inspiration for other business to follow policies conducive to the environment. As a result economy will receive more products without sacrificing the environment.

Health care for poor: One of the reasons for our extreme poverty is that the poor have to sell their last resort for treatment. There are government efforts to provide free or low cost treatment but these are insufficient. So, many poor people either die or lose even their last resort. Social business may be of great help in ensuring health care for all those who are below poverty line.

Removing social unrest: Unemployment and poverty are the major sources of social unrest. Thus, fulfilling basic needs and generating employment social business can fix the problem of social unrest.

\section{Social Business in Bangladesh}

At least six companies that are currently in operation in Bangladesh have been established as social business company under the direct supervision and management of Muhammad Yunus. They are namely Grameen Danone, Grameen Veolia, BASF Grameen, Grameen Intel, Grameen GC Eye Care Hospital, Grameen Bank. These companies are producing yogurt, water, mosquito net, IT product and eye care services, and micro credit respectively. Table 2 illustrates the facts and social impacts of these companies.

Table-2: Social business companies in operation: facts and social impacts

\begin{tabular}{|c|c|c|}
\hline Company & Facts & Social Impacts \\
\hline $\begin{array}{l}\text { Grameen } \\
\text { Bank }\end{array}$ & $\begin{array}{l}\text { Ownership: } 90 \% \text { by the } \\
\text { borrowers, } 10 \% \text { by the } \\
\text { government } \\
\text { Launching date: October } \\
1983 \\
\text { Product: Microcredit with no } \\
\text { collateral and minimum } \\
\text { paper works } \\
\text { Special feature: Bank } \\
\text { officials goes to the borrower }\end{array}$ & $\begin{array}{l}\text { - Vicious cycle of poverty } \\
\text { started breaking. } 64 \% \text { of } \\
\text { the borrowers who have } \\
\text { been with the bank for } 5 \\
\text { years or more have } \\
\text { crossed the poverty line. } \\
\text { - Huge self-employment } \\
\text { by the poor people has } \\
\text { taken place. }\end{array}$ \\
\hline
\end{tabular}




\begin{tabular}{|c|c|c|}
\hline $\begin{array}{l}\text { Grameen } \\
\text { Danone } \\
\text { Food } \\
\text { Limited }\end{array}$ & $\begin{array}{l}\text { Ownership: Grameen group } \\
\text { and French Group Danone } \\
\text { Launching date: late } 2006 \\
\text { Product: Yogurt } \\
\text { Special feature: Uses solar } \\
\text { and biogas energy }\end{array}$ & $\begin{array}{l}\text { - Poor parents now have } \\
\text { low cost solution to the } \\
\text { malnutrition problem of } \\
\text { their children. } \\
\text { - Many including } \\
\text { Grameen members got } \\
\text { employed }\end{array}$ \\
\hline $\begin{array}{l}\text { Grameen } \\
\text { GC Eye } \\
\text { Care } \\
\text { Hospital }\end{array}$ & $\begin{array}{l}\text { Ownership: Grameen group } \\
\text { and The Green Children } \\
\text { Launching date: May } 2008 \\
\text { Product: Eye care especially } \\
\text { cataract operation } \\
\text { Special feature: Charges } \\
\text { patients according to their } \\
\text { ability to pay }\end{array}$ & $\begin{array}{l}\text { - Preventing blindness } \\
\text { - Employment generation }\end{array}$ \\
\hline $\begin{array}{l}\text { Grameen- } \\
\text { Veolia } \\
\text { Water } \\
\text { Limited }\end{array}$ & $\begin{array}{l}\text { Ownership: Grameen } \\
\text { Healthcare Services and } \\
\text { Veolia Water AMI } \\
\text { Launching date: March } 2008 \\
\text { Product: Pure drinking water } \\
\text { Special feature: Treats } \\
\text { surface water according to } \\
\text { WHO standard }\end{array}$ & $\begin{array}{l}\text { - Elimination of water } \\
\text { transmitted diseases and } \\
\text { arsenic related disease } \\
\text { - Employment generation }\end{array}$ \\
\hline $\begin{array}{l}\text { Grameen } \\
\text { BASF }\end{array}$ & $\begin{array}{l}\text { Ownership: Grameen group } \\
\text { and BASF SE Germany } \\
\text { Launching date: March } 2009 \\
\text { Product: Impregnated } \\
\text { mosquito net, micronutrient } \\
\text { sachets } \\
\text { Special feature: Provides } \\
\text { high quality products at low } \\
\text { cost }\end{array}$ & $\begin{array}{l}\text { - Protecting the poor from } \\
\text { mosquito transmitted } \\
\text { deadly diseases } \\
\text { - Providing essential } \\
\text { nutrients for the poor } \\
\text { - Employment generation }\end{array}$ \\
\hline $\begin{array}{l}\text { Grameen } \\
\text { Intel }\end{array}$ & $\begin{array}{l}\text { Ownership: Grameen Trust } \\
\text { and Intel } \\
\text { Launching date: } 2009 \\
\text { Product: Information } \\
\text { communication technology } \\
\text { (ICT) solution to health and } \\
\text { agriculture related problems }\end{array}$ & $\begin{array}{l}\text { - Most advanced solution } \\
\text { to health and agriculture } \\
\text { related problems with } \\
\text { minimal time and } \\
\text { reachable cost } \\
\text { - Employment generation }\end{array}$ \\
\hline
\end{tabular}


Special feature: Digital solutions in remote rural area

Source: Constructed by the author on the basis of information found from http://www.muhammadyunus.org/ last accessed on June 18, 2011

\section{Limitations and Criticism ${ }^{2}$}

Although the idea of social business has so far been able to draw ample attention of academicians, researchers as well as practitioners around the world, it has been subject to criticism for some of its inherent limitations. A very brief discussion on its limitations and criticisms is presented below:

Motivational factor: As Yunus argues, 'social passion' motivates an entrepreneur to run a social business. Considering the common psychology of entrepreneurs (as human being) it would not be unreasonable to raise a question as to whether the 'social passion' is robust enough as a motivational factor to prompt an entrepreneur to go for a social business. Someone may argue that a person's becoming an entrepreneur of social business out of only 'social passion' can be seen as an accident rather than a regular phenomenon.

Performance Measurement Criteria: The main target of the social business is to achieve social objectives. But it is still not clear how to measure the performance of a social business company in achieving those objectives. No concrete tool has been devised as performance measuring criteria. It is in fact difficult to measure such non-monetary achievement.

Free Riding Problem: Social business firms are supposed to compete with each other in a cooperative manner to bring about social improvement which is of public nature. But it is well known that public good as well as group action without individual interest generally involves free-riding problem.

Special Quality and Special Risk: Since the entrepreneurs in social business need to achieve social goals subject to no loss condition, they have to face the challenges PMB and the social problems at the same time. Thus, they must have special quality in making decision and dealing with risk and uncertain situations. But the question is whether any such highly skilled person will be interested to run the business without any individual profit. 
Time Value of Money: In social business, the owner who invests the fund is paid back only the original amount after a specific time period and he is not entitled to get any profit. But as there is no consideration of time value of money the owner may bound to bear loss.

Misuse of social business: One can do profit maximizing business and social business at the same time. So there is a great possibility of misuse of the social business as a promotional tool for product market or experiment achieving tool for their profit maximizing business. On the other hand, as investors have no individual interest, there might arise mismanagement on the part of entrepreneurs.

\section{Poverty Situation in Bangladesh and the Scope of Social Business}

According to the Household Income and Expenditure Survey (HIES) of Bangladesh Bureau of Statistics (BBS), the national poverty headcount rate in Bangladesh has declined gradually but still it was 31.5 percent in 2010. The survey also reports that $17.6 \%$ (approximately 25 million) people of the country were living in extreme poverty in 2010 .

In view of the poverty situation in Bangladesh, an effective and pragmatic effort needs to be put to overcome the hurdles on the way to achieve the goal of halving poverty by 2015 , which is of highest priority among the Millennium Development Goals (MDGs). Social business may be thought of as an important instrument in that effort. Bangladesh government in a report entitled "A Situation Analysis Report on Poverty and Hunger (MDG 1) Bangladesh - A Baseline for Needs Assessment and Costing" identifies the following four challenges in reducing poverty: reducing hunger and malnutrition, youth employment, promoting pro-poor growth and expansion of urban employment. In fact, these challenges are the core issues that the idea of social business tries to address. As mentioned earlier, several social business companies are already in operation in this country and they are apparently on a trajectory of success. It is therefore reasonable to argue that the scope of social business in Bangladesh is much promising.

\section{Conclusion}

The idea of social business is still in its nascent stage. Being a very new and incomparable subject, it may take some more time to assume a full-fledged and mature structure in both conceptual and operational 
dimensions. Considering the immense need of poverty alleviation and the perspective in which poverty exists, it can be said that winning the war against poverty in Bangladesh requires innovative efforts like promoting the idea of social business model and proper implementation of them.

\section{References:}

1. Akteruzzaman, Md. (undated). "A Situation Analysis Report on Poverty and Hunger (MDG 1) Bangladesh - A Baseline for Needs Assessment and Costing". General Economics Division, Planning Commission, Government of the People's Republic of Bangladesh \& UNDP Bangladesh.

2. Bangladesh Bureau of Statistics, 2010. "Household Income and Expenditure Survey (HIES)". The Government of Bangladesh, Dhaka.

3. Bylund, Per L. and Mario Mondelli, 2009. "Book Review: Creating a World without Poverty: Social Business and Future Capitalism". The Electronic Journal of Sustainable Development. Found at http://www.ejsd.org/docs/REVIEW_OF_CREATING_A_WORLD_WIT HOUT_POVERTY.pdf, last accessed on June 20, 2011.

4. Donaldson, Cam, Rachel Baker, Francine Cheater, Morag Gillespie, Neil McHugh and Stephen Sinclair 2011. "Social business, health and wellbeing", Social Business, Volume 1, Number 1, Spring. Abstract found at http://www.ingentaconnect.com/content/westburn/sb/2011/00000001/000 00001/art00002 last accessed on July 29, 2012.

5. Sattar, Z. 2012. "Social business: Turning Capitalism on its Head". Found at http://www.thedailystar.net/forum/2012/January/social.htm last accessed on July 29, 2012.

6. United Nations Development Program (UNDP) website at http://www.undp.org/content/undp/en/home/mdgoverview.html last accessed on July 30, 2012. 
IIUC Studies, Vol. 8

7. Wimmer, N. 2012. "Green Energy for a Billion Poor: How Grameen Shakti Created a Winning Model for Social Business". MCRE verlag UG. Found at http://www.amazon.com/Green-Energy-Billion-PoorBusiness/dp/3943310000 last accessed on July 29, 2012.

8. World Hunger website at http://www.worldhunger.org/ articles/ Learn/ world\%20hunger\%20facts\%202002.htm last accessed on June 20, 2011.

9. Younus Center website at http://www.muhammadyunus.org/ last accessed on June 18, 2011.

10. Yunus, Muhammad and Alan Jolis, 2007a. "Banker to the Poor: Microlending and the Battle against World Poverty”. Public Affairs, New York.

11. Yunus, Muhammad and Karl Weber, 2007b. "Creating a World without Poverty: Social Business and Future Capitalism”. Public Affairs, New York.

12. Yunus, Muhammad and Karl Weber, 2010. "Building Social Business: the New Kind of Capitalism that Serves Humanity's Most Pressing Needs". Public Affairs, New York.

13. Yunus, Muhammad, Moingeon, Bertrand and Lehmann-Ortega Laurence, 2009. "Building Social Business Models: Lessons from the Grameen Experience". Working Paper 913, HEC, Paris.

\footnotetext{
${ }^{1}$ Veolia Water's subsidiary for Africa, the Middle East and the Indian subcontinent

${ }^{2}$ Large portion of this section is based on Bylund and Mondelli (2009)
} 